\title{
PRECIPITIN STUDIES IN NEPHROSIS AND NEPHRITIS
}

\author{
By E. GOETTSCH and J. D. LYTTLE \\ (From the Department of Pediatrics, College of Physicians and Surgeons, \\ Columbia University, New York)
}

(Received for publication July 13, 1939)

In a previous paper (1) measurements by the quantitative precipitin method were reported which demonstrated an immunologic difference between normal serum proteins and the serum proteins from a few patients during the edematous stage of nephrosis; the sera from the nephrotic patients failed to precipitate completely with specific antisera. Coincident with clinical improvement following diuresis both albumin and globulin regained their normal behavior. The serum proteins of a few nephritic patients did not show such marked failure to react.

Since the sera from nephrotic patients reacted incompletely with anti-normal albumin and antinormal globulin sera, it was suspected that the part of the protein which reacted had retained the serological characteristics of normal protein, and that the remainder of the protein was changed in some peculiar fashion. The altered protein disappeared gradually during convalescence following diuresis. Hence it was assumed that during the edematous stage of nephrosis the serum proteins were mixtures of normal and altered protein with the altered protein usually predominating; after diuresis with clinical improvement, the altered protein decreased in favor of an increase of the normal protein.

This peculiar property of the serum proteins of nephrotic patients aroused curiosity on several points. Is the change in the serum protein present early in the course of the nephrosis? Can the amount of altered serum protein be correlated with any of the important clinical features of nephrosis such as superimposed infection, albuminuria, cholesteremia, or edema? Can an arbitrary level of the altered protein be selected which will differentiate nephrotic from nephritic sera in order to secure more accurate diagnosis and prognosis in kidney disease in children? What is the nature of the altered protein? Is altered protein present in the sera of patients with diseases other than nephrosis and nephritis?
The purpose of this report is to present observations on a larger series of patients over a period of 3 years in an attempt to answer the above questions. Twenty-three patients with nephrosis and 17 with nephritis have been studied. Frequent observations were made on 19 of the nephrotic patients until death occurred or recovery ensued; in the remaining 4 cases one observation was made for diagnostic purposes only; in 11 of the 17 nephritic patients prolonged studies were possible.

In Table $I$ the analyses on the sera of 6 of the 23 patients with nephrosis are assembled, together with some of the pertinent clinical findings. The values obtained with the quantitative precipitin method are compared with the results by Howe's method; the difference between the two values was considered to represent the altered protein; that is, the protein which showed abnormal serological reaction. The technics used have been described previously (2). An examination of the data reveals that in each patient at some time during the course of the disease the amount of altered albumin was 40 per cent or more of the total albumin as determined by Howe's method; the globulin, on the other hand, was unaffected in some patients and showed varying amounts of altered globulin in others. In 17 cases both altered albumin and altered globulin were found, while in 5 cases the albumin only was affected.

1. Is the change in the serum proteins present early in the course of nephrosis? It is important to determine whether the change in the serum protein appears early enough in the course of nephrosis to be of primary etiologic significance; or whether it appears after prolonged albuminuria or persistent malnutrition has presumably strained the mechanism for the synthesis of serum protein. If it could be demonstrated that the altered protein were present before albuminuria had occurred or before severe malnutrition were a complicating factor, it would be justifiable to accord 
TABLE I

Analyses of sera from cases of nephrosis. Comparison of Howe's method and the precipitin method

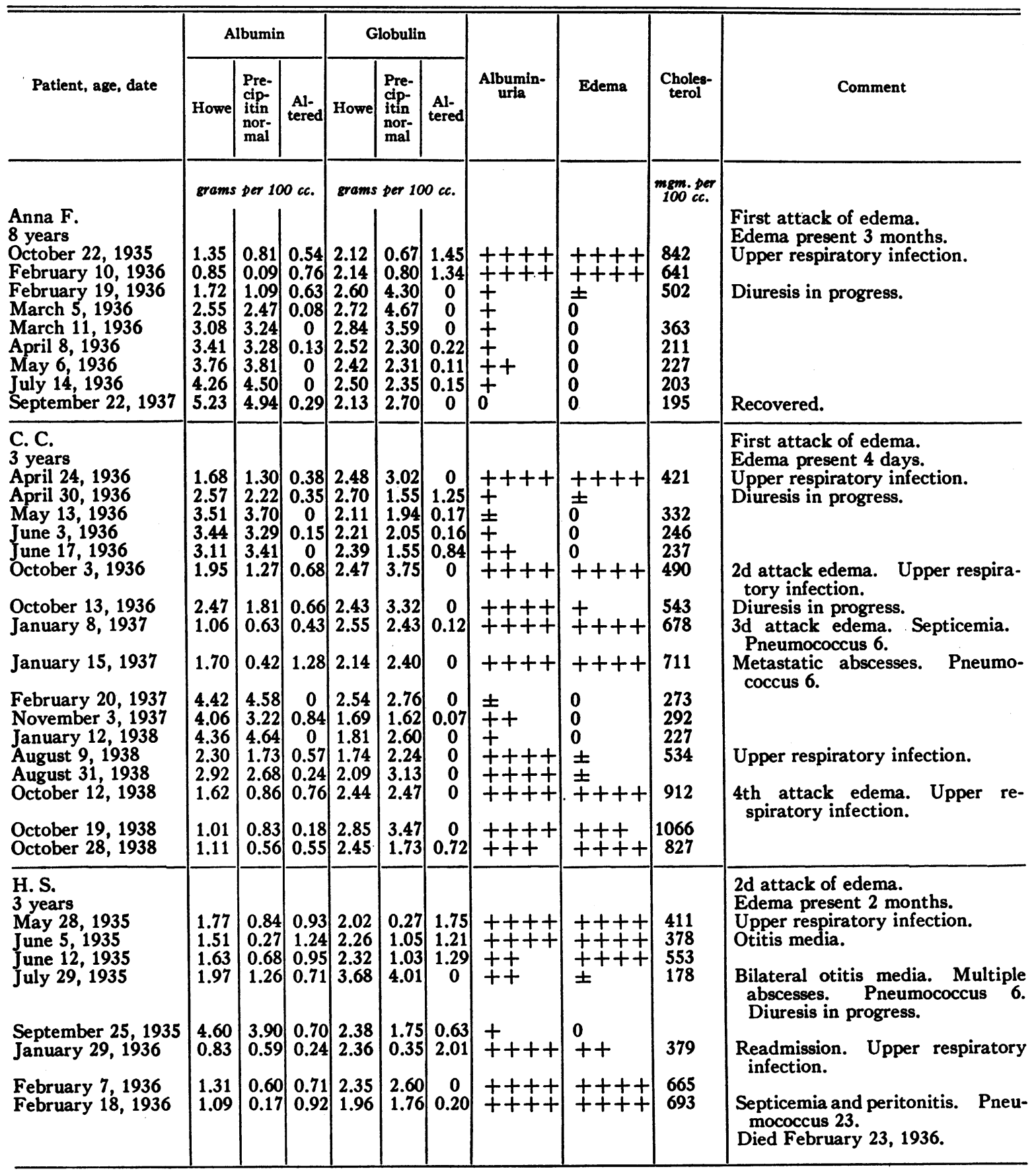


TABLE I-Continued

\begin{tabular}{|c|c|c|c|c|c|c|c|c|c|c|}
\hline \multirow[b]{2}{*}{ Patient, age, date } & \multicolumn{3}{|c|}{ Albumin } & \multicolumn{3}{|c|}{ Globulin } & \multirow[b]{2}{*}{$\underset{\text { uria }}{\text { Albumin- }}$} & \multirow[b]{2}{*}{ Edema } & \multirow[b]{2}{*}{$\begin{array}{c}\text { Choles- } \\
\text { terol }\end{array}$} & \multirow[b]{2}{*}{ Comment } \\
\hline & Howe & $\begin{array}{l}\text { Pre- } \\
\text { cip- } \\
\text { itin } \\
\text { nor- } \\
\text { mal }\end{array}$ & $\begin{array}{c}\text { Al- } \\
\text { tered }\end{array}$ & Howe & $\begin{array}{l}\text { Pre- } \\
\text { cip- } \\
\text { itin } \\
\text { nor- } \\
\text { mal }\end{array}$ & \begin{tabular}{|c|} 
Al- \\
tered
\end{tabular} & & & & \\
\hline $\begin{array}{l}\mathrm{J} . \mathrm{J} \\
2 \frac{1}{2} \text { years } \\
\text { October } 27,1937 \\
\text { November } 15,1937\end{array}$ & $\begin{array}{l}1.35 \\
1.67\end{array}$ & $\begin{array}{l}0.58 \\
0.50\end{array}$ & $\begin{array}{l}0.77 \\
1.17\end{array}$ & $\begin{array}{l}2.31 \\
2.17\end{array}$ & $\begin{array}{l}2.02 \\
2.84\end{array}$ & $\begin{array}{c}0.29 \\
0\end{array}$ & & + & $\begin{array}{l}\text { mgm. per } \\
100 \text { cc. } \\
892 \\
635\end{array}$ & $\begin{array}{l}\text { First attack of edema. } \\
\text { Edema present } 8 \text { days. } \\
\text { Upper respiratory infection. } \\
\text { Bronchopneumonia. Pneumococ- }\end{array}$ \\
\hline $\begin{array}{l}\text { November } 26,1937 \\
\text { December } 1,1937 \\
\text { December } 13,1937 \\
\text { September } 9,1938 \\
\text { October } 10,1938\end{array}$ & $\begin{array}{l}2.56 \\
3.12 \\
4.14 \\
5.00 \\
4.11\end{array}$ & $\begin{array}{l}1.00 \\
2.08 \\
4.06 \\
5.12 \\
3.68\end{array}$ & $\begin{array}{c}1.56 \\
1.04 \\
0.08 \\
0 \\
0.43\end{array}$ & $\begin{array}{l}2.74 \\
3.11 \\
2.51 \\
1.86 \\
2.12\end{array}$ & $\begin{array}{l}5.37 \\
4.96 \\
5.00 \\
1.97 \\
2.81\end{array}$ & $\begin{array}{l}0 \\
0 \\
0 \\
0 \\
0\end{array}$ & $\begin{array}{l}+ \\
+ \\
0 \\
0 \\
++++\end{array}$ & $\begin{array}{l} \pm \\
0 \\
0 \\
0 \\
0\end{array}$ & $\begin{array}{l}410 \\
350 \\
346 \\
248 \\
333\end{array}$ & $\begin{array}{l}\text { Diuresis in progress. } \\
\text { Readmission. Tonsillectomy. } \\
\text { 2d attack edema. Upper respira- }\end{array}$ \\
\hline $\begin{array}{l}\text { October 14, } 1938 \\
\text { October 19, } 1938 \\
\text { November 1, } 1938 \\
\text { November } 8,1938 \\
\text { November 21, } 1938 \\
\text { December 2, } 1938 \\
\text { December } 17,1938\end{array}$ & $\begin{array}{l}3.35 \\
2.72 \\
1.99 \\
2.28 \\
2.70 \\
3.32 \\
4.16\end{array}$ & $\begin{array}{l}2.86 \\
2.25 \\
1.23 \\
1.45 \\
2.01 \\
2.82 \\
3.87\end{array}$ & $\begin{array}{l}0.49 \\
0.47 \\
0.76 \\
0.83 \\
0.69 \\
0.50 \\
0.29\end{array}$ & $\begin{array}{l}2.35 \\
1.92 \\
2.55 \\
2.23 \\
2.41 \\
2.13 \\
2.03\end{array}$ & $\begin{array}{l}2.48 \\
1.93 \\
3.72 \\
2.73 \\
2.99 \\
1.94 \\
2.50\end{array}$ & $\begin{array}{c}0 \\
0 \\
0 \\
0 \\
0 \\
0.19 \\
0\end{array}$ & $\begin{array}{l}+- \\
+- \\
+-1 \\
+- \\
+ \\
\pm \\
\pm\end{array}$ & $\begin{array}{l}0 \\
0 \\
0 \\
\pm \\
\pm \\
0 \\
0\end{array}$ & $\left.\begin{array}{l}357 \\
414 \\
525 \\
590 \\
590 \\
552 \\
333\end{array}\right\}$ & Mild upper respiratory infection. \\
\hline $\begin{array}{l}\text { L. G. } \\
2 \text { years } \\
\text { October 28, 1935 } \\
\text { November 11, } 1935\end{array}$ & $\begin{array}{l}1.98 \\
1.83\end{array}$ & $\begin{array}{l}0.87 \\
0.89\end{array}$ & $\begin{array}{l}1.11 \\
0.94\end{array}$ & $\begin{array}{l}2.73 \\
2.61\end{array}$ & $\begin{array}{l}0.60 \\
0.47\end{array} \mid$ & \begin{tabular}{|l|}
2.13 \\
2.14
\end{tabular} & $\stackrel{t}{+}$ & $\begin{array}{l}+t+ \\
++t\end{array}$ & $\begin{array}{l}611 \\
758\end{array}$ & $\begin{array}{l}\text { First attack of edema. } \\
\text { Edema present } 6 \text { days. } \\
\text { Mild upper respiratory infection. } \\
\text { Died } 6 \text { months later. }\end{array}$ \\
\hline $\begin{array}{l}\text { J. F. } \\
5 \text { years } \\
\text { June } 22,1934 \\
\text { June } 27,1934 \\
\text { July } 9,1934 \\
\text { July } 14,1934 \\
\text { October } 8,1934 \\
\text { December } 13,1934 \\
\text { January } 28,1935 \\
\text { February } 25,1935 \\
\text { May } 13,1935\end{array}$ & $\begin{array}{l}1.17 \\
1.01 \\
1.27 \\
1.30 \\
0.91 \\
2.75 \\
3.10 \\
2.86 \\
3.87\end{array}$ & $\begin{array}{l}0.20 \\
0.26 \\
0.31 \\
0.27 \\
0.22 \\
2.33 \\
2.63 \\
2.50 \\
3.56\end{array}$ & $\begin{array}{l}0.97 \\
0.75 \\
0.96 \\
1.03 \\
0.69 \\
0.42 \\
0.47 \\
0.36 \\
0.31\end{array}$ & $\begin{array}{l}2.60 \\
2.71 \\
2.81 \\
2.30 \\
2.31 \\
2.57 \\
2.09 \\
2.20 \\
2.24\end{array}$ & $\begin{array}{l}0.88 \\
1.03 \\
1.02 \\
0.84 \\
1.17 \\
1.76 \\
1.48 \\
1.10 \\
1.07\end{array}$ & $\begin{array}{l}1.72 \\
1.68 \\
1.79 \\
1.46 \\
1.14 \\
0.81 \\
0.61 \\
1.10 \\
1.17\end{array}$ & $\begin{array}{l}++- \\
++- \\
++- \\
++- \\
++ \\
+ \\
+ \\
+ \\
+\end{array}$ & $\begin{array}{l}++++ \\
++++ \\
++++ \\
+++ \\
++++ \\
0 \\
0 \\
0 \\
0\end{array}$ & $\begin{array}{l}689 \\
718 \\
668 \\
599 \\
475 \\
378 \\
496\end{array}$ & $\begin{array}{l}\text { Hemolytic streptococcus infection. } \\
\text { Died June 11, 1936. Peritonitis } \\
\text { and septicemia. Pneumococcus } \\
20 .\end{array}$ \\
\hline
\end{tabular}

the alteration in the protein a significant etiological rôle.

Of the 23 nephrotic patients only 5 were admitted early enough to provide information on this point. In the 5 patients edema had first been noted from 4 to 21 days preceding admission to the hospital for an initial attack of nephrosis. In no patient was severe infection present either at the onset of symptoms or on admission. In the remaining 18 children edema had been present at least 1 month before admission. In 3 patients studies were made 6,8 , and 21 days after the onset of edema and in all 3 the derangement of the serum proteins had already developed to the maximum extent. The data on 2 of these pa- tients, L. G. and J. J., are included in Table I. It is significant that in 2 of these patients edema and albuminuria were likewise maximal on admission and persisted for some time. In the third patient (L. G.), however, the albuminuria was slight on entry 6 days after edema had appeared, yet the serum protein derangement was maximal. In contrast, in 2 patients in whom studies were made 4 and 14 days after the onset of edema the serum proteins showed changes of lesser degree on admission. Patient C. C., reported in Table I, observed 4 days after the onset of edema, presented milder changes in the serum proteins; yet the clinical findings and history were quite similar to those found in patient L. G. in whom the pro- 
tein alterations were marked. Maximal changes appeared in this patient later. Thus in 3 out of 5 patients maximal alteration was present in the serum proteins very early in the course of nephrosis uncomplicated by severe infection. In the remaining 2 patients the amount of altered protein was less on admission and increased as the disease progressed.

In 2 patients it was possible to study the serological reactions during recurrence of edema following a remission. Patient $\mathrm{H}$. S., whose record appears in Table I, had shown maximal amounts of altered serum protein during a long period of edema with the characteristic reduction in the amount of altered protein during a remission. Four months later, on readmission 5 days after edema had appeared, the altered protein was again present in maximal quantities even in so short a time. In the second patient, J. J., as shown in Table I, the serum protein changes were maximal, with 57 per cent altered albumin, 8 days after the onset of edema. Bronchopneumonia developed and the altered albumin increased to 70 per cent. Four weeks later the edema and albuminuria had disappeared and the serum proteins had regained the normal level. Serologically, the albumin behaved like normal albumin while the globulin presented a high value with the precipitin method which is characteristic of rapidly regenerating serum protein. During the following 9 months the child had measles and several upper respiratory infections without a recurrence of edema or albuminuria. Studies revealed that the serum proteins were normal qualitatively and serologically. Ten months after the initial attack he was admitted to the hospital because heavy albuminuria had recurred. No edema was demonstrable and the only infection noted was a mild upper respiratory infection. The serum albumin was 4.11 grams per $100 \mathrm{cc}$. with only 10 per cent of altered albumin. During the next 4 weeks the serum albumin dropped gradually to 1.99 grams per $100 \mathrm{cc}$. and the altered albumin rose to 38 per cent. Albuminuria persisted and, although the eyelids appeared somewhat puffy, it was not until the end of this period that mild pitting edema of the shins could be demonstrated. Without complicating infection the edema and albuminuria disappeared gradually and the serum proteins again regenerated to the normal level.

The data which have been presented demonstrate conclusively that large amounts of altered protein may be found very early in the course of the disease; for example, in patient L. G. as early as 4 days after the first appearance of edema and 12 days following the mild upper respiratory infection which initiated the illness. Albuminuria was slight on admission, but the duration of preceding albuminuria, if any, could not be ascertained. None of the children in this group presented evidence of severe malnutrition. The data suggest that the alteration of the serum protein is of primary importance and precedes malnutrition; but the data are insufficient to demonstrate whether albuminuria precedes or follows the change in protein. In 1 case, L. G., evidence strongly suggests that the serological change precedes the albuminuria; on the other hand in another patient, J. J., during the reaccumulation of edema in a second attack, the serum changes were minimal and increased as albuminuria persisted.

2. Can the amount of altered serum protein be correlated with any of the important clinical features of nephrosis such as superimposed infection, albuminuria, cholesteremia, or edema?

Relation of the altered serum protein to superimposed infection. It may be inquired whether a correlation exists between the amount of the altred protein and the severity of a superimposed infection. Two nephrotic patients of the series were admitted with severe fatal pneumococcic infection and in both children the amount of altered protein was maximal on admission. The other 21 patients entered the hospital with mild upper respiratory infections, including 1 case with an otitis media. In 17 of these patients a high percentage of altered protein was found. Thus 81 per cent of the patients with a mild upper respiratory disturbance as the sole clinical sign of infection on admission revealed amounts of altered serum protein of the same magnitude as 2 patients who were critically ill with fatal superimposed pneumococcic infections.

Three patients with mild upper respiratory infections on admission presented lesser amounts of altered protein and later in the course of the disease the amounts became maximal. In two 




Fig. 1. Relation of Altered and Normal Serum Albumin to Edema

instances the altered protein increased within 3 weeks with no apparent change in the clinical condition. In the third patient, C. C., recorded in Table I, the increase of altered protein paralleled the severity of the added infection on one occasion but did not do so later in the course of the disease.

Hence no consistent relation could be demonstrated between the amount of altered protein and the severity of the superimposed infection.

Relation of the amount of altered serum albumin to edema. Since the sera of all patients with nephrosis exhibited large amounts of altered albumin an attempt was made to evaluate the relation of the altered albumin to the edema. The amount of edema was classified as maximum if generalized anasarca, including ascites, was present; as moderate if generalized edema without ascites was found; as minimum if edema was localized. Scatter diagrams (Figure 1) were made by plotting the amount of edema against both the values of altered albumin and those of normal albumin. The diagrams show no relation between the amount of altered albumin and the edema, while the expected correlation exists between the amount of normal albumin and the edema.

Relation of the altered serum albumin to the albuminuria. Similarly an attempt was made to evaluate the relation of the altered albumin to the albuminuria. The albuminuria was classified as heavy, moderate, or slight on the basis of qualitative tests in routine urine specimens. The scatter diagram from these data is presented in Figure 2. It likewise fails to reveal any relationship between the altered albumin and the albuminuria.

Relation of the altered serum albumin to cholesteremia. To investigate the possibility of a relationship between altered albumin and the level of serum cholesterol a diagram (Figure 3) was prepared in which the values for altered albumin were plotted against the total serum cholesterol. It is apparent that no relationship exists. In- 
cluded in Figure 3 is a diagram of the relation of normal serum albumin to total serum cholesterol. It is clear that normal values for total cholesterol are always associated with normal levels of normal serum albumin. The cholesterol analyses included estimations of the free and esterified fractions after the method of Schoenheimer and Sperry (3). Frequently in nephrosis rapidly while the regeneration of the serum protein requires considerable time. The altered protein, cholesteremia, and albuminuria likewise decrease gradually. Hence, high correlations between these manifestations cannot be expected.

It was futile to speculate on the possibility of a correlation between the altered globulin and edema and the other pertinent clinical findings of

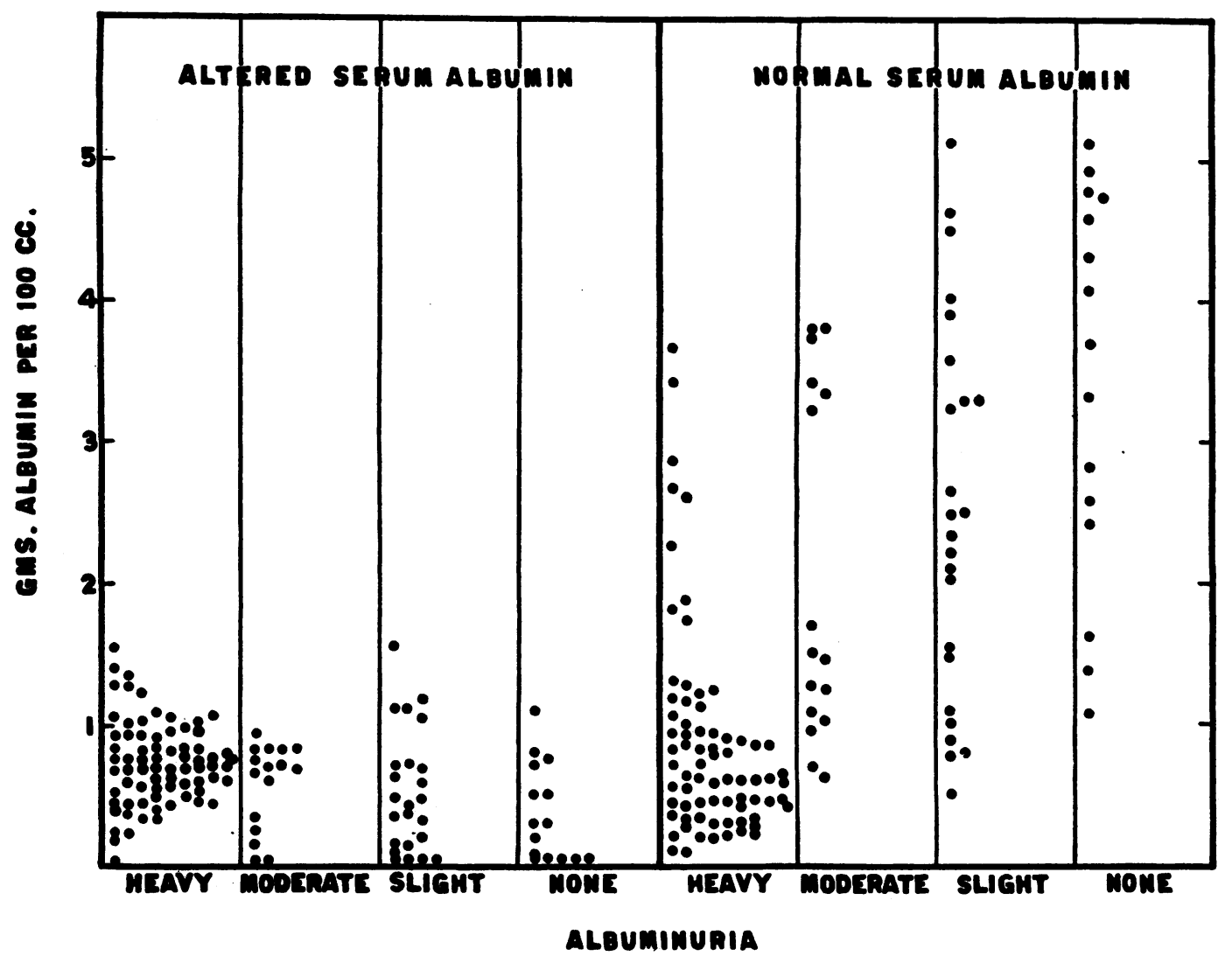

Fig. 2. Relation of Altered and Normal Serum Albumin to Albuminuria

the ratio of cholesterol ester to cholesterol is moderately low. Previously (4) it was found that a low ratio indicates either hepatic disease or infection and is independent of the amount of total cholesterol. When the ratios are plotted against the levels of total cholesterol (Figure 4), it is clear that the lowered ratios found in nephrotic sera are likewise not associated with the high values of total cholesterol.

Studies of the natural history of nephrosis have shown that following diuresis clinical and laboratory findings return slowly but not simultaneously to the normal level. The edema disappears quite nephrosis, because in some patients no altered globulin could be demonstrated during the entire illness. There was no difference clinically between the cases which showed altered globulin and those in which it was never demonstrated. It is possible that the failure to demonstrate altered globulin may be explained by a curious reaction of regenerating globulin to the specific antiserum. Under circumstances in which there is reason to believe that new globulin is being formed in response to infection with the production of antibodies, or when new serum protein is being rapidly regenerated following a depletion, 


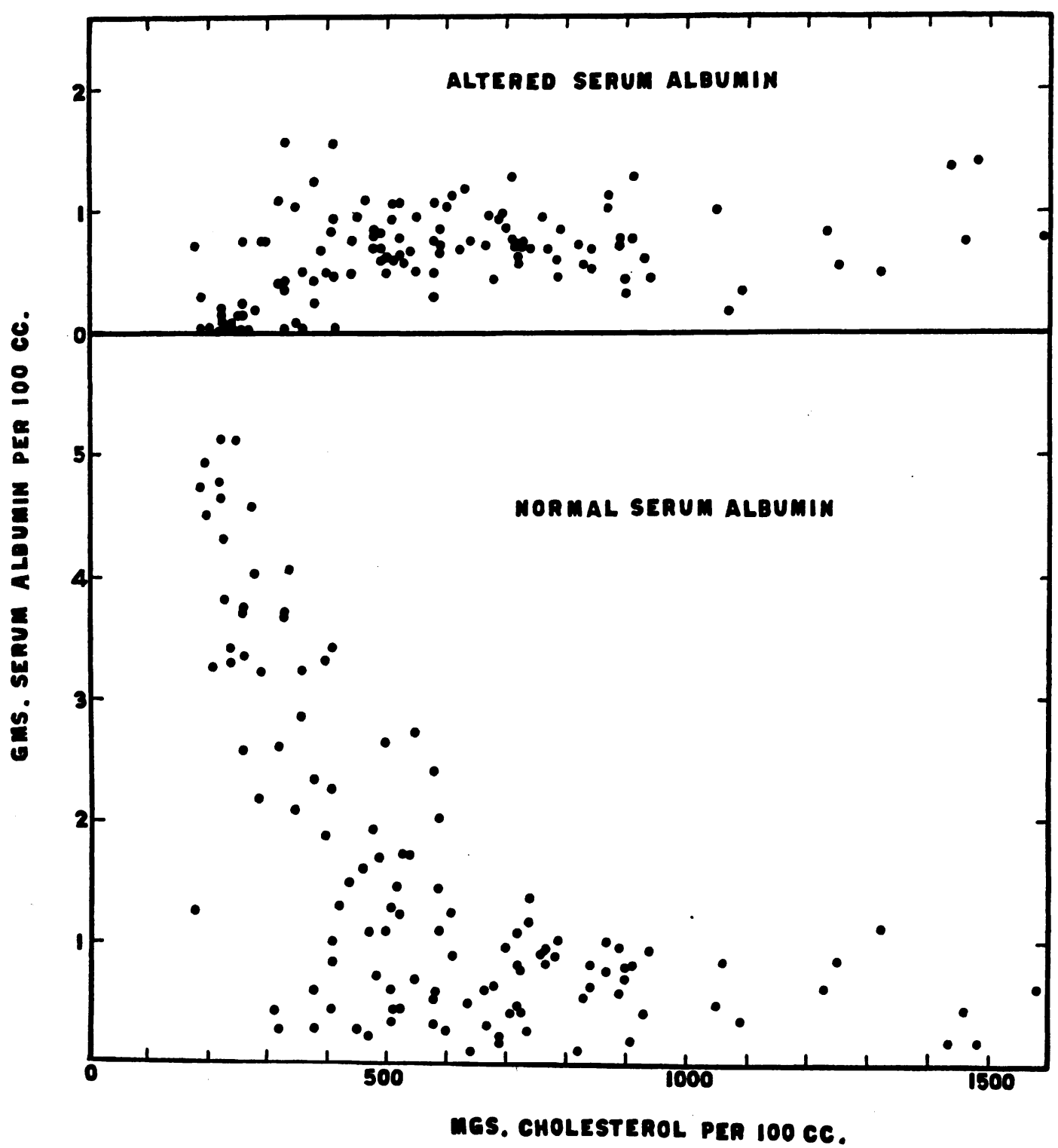

Fig. 3. Relation of Altered and Normal Serum Albumin to Serum Cholesterol

a disturbance in the distribution of globulin subfractions, as determined by Howe's method, will be reflected in a high precipitin value. As the stimulus to infection or regeneration recedes, the globulin sub-fractions gradually revert to normal and then the precipitin values are also normal. Such a series of changes may be followed in Table $\mathrm{I}$ in patients $\mathrm{H}$. S. and J. J. where the stimulus was apparently severe infection, and in patients C. C., J. J., and A. F., when serum protein was regenerating rapidly during convalescence. In patients C. C., J. J., and A. F., in whom the serum proteins regained the normal value following diuresis, the globulin values obtained by the precipitin method eventually became normal. The failure to demonstrate significant amounts of altered globulin in patient J. J. and others during the edematous stage may be the result of such forces. No correlation could be demonstrated between any single globulin sub-fraction and the excessive value obtained by the precipitin method. The difficulties involved in the separation of the glo- 


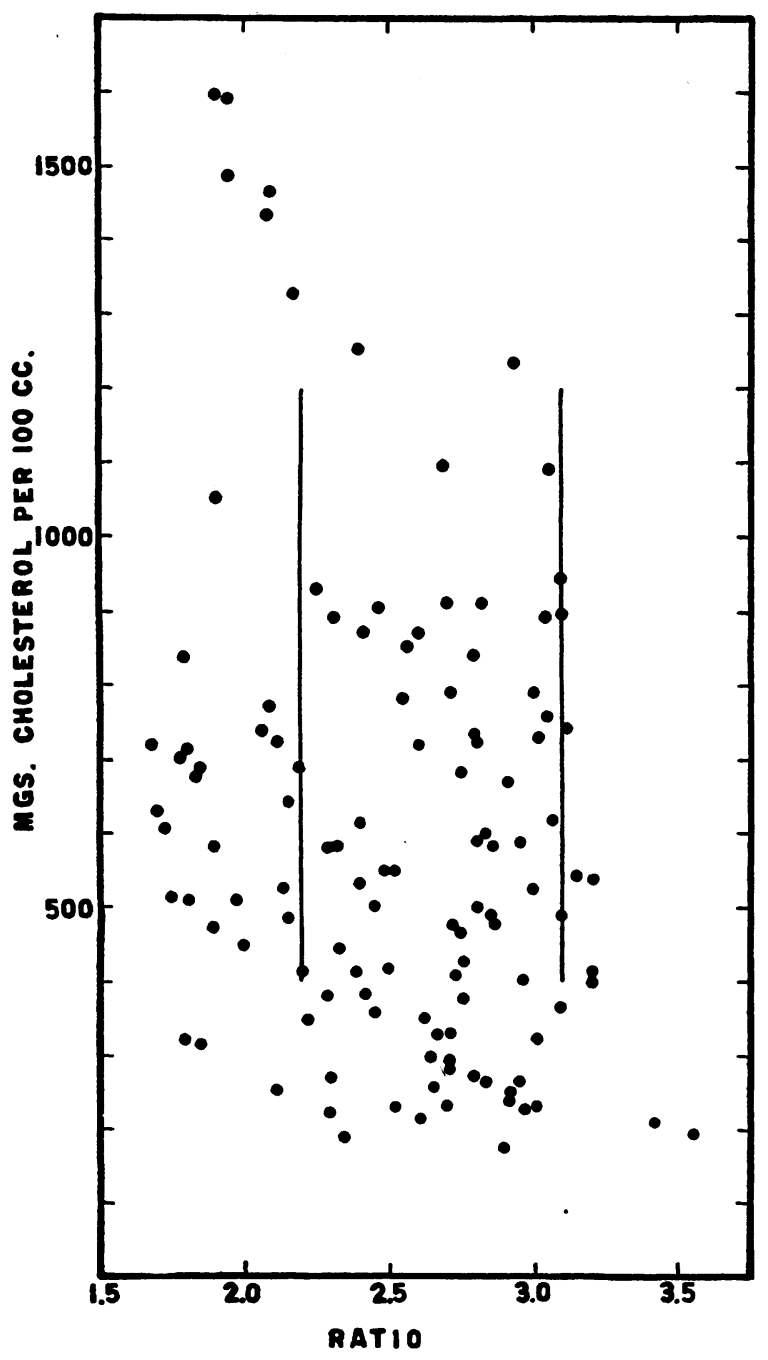

Fig. 4. Relation of Serum Cholesterol to the Ratio of Cholesterol Ester to Free Cholesterol

The lines indicate the limits of the ratio for normal sera.

bulin sub-fractions by salt precipitation in highly lipoidal serum are legion. Satisfactory separation could not be obtained in this laboratory even with the use of a high-speed centrifuge. The data obtained on sera subjected to fractional analysis, presented in Table II, show that the high precipitin values cannot be related to a change in any one globulin sub-fraction.

3. Can an arbitrary level of altered protein be selected which will distinguish nephrotic from nephritic patients in order to secure more accurate diagnosis and prognosis in kidney disease in children? Seventeen cases of acute glomerular ne- phritis were studied in a similar fashion. In 11 cases prolonged studies were possible and in the remaining 6 cases one or two observations only were made. The data from a few patients are collected in Table III. In all cases the altered albumin was less than 50 per cent of the total albumin by Howe's method; however, the total amount of altered albumin was often as much as that found in some nephrotic patients. Change in the globulin fraction was rarely present and was always minimal. The contrast between the findings in acute glomerular nephritis and in nephrosis is brought out in Figure 5, in which the highest percentage of altered albumin found in each patient is charted. Three nephrotic sera and 3 nephritic sera presented between 40 and 50 per cent of altered albumin. In 2 of the nephrotic sera presenting such changes an accompanying change in the globulin fraction of 40 per cent or more appeared at some time during the course of the disease. The altered albumin in acute glomerular nephritis is always transient, while in nephrosis the change usually persists for long periods of time. In the 2 cases of nephritis in which the percentage of altered albumin was above 40 per cent on admission, i.e., in patients J. D. and R. V., the percentage of altered albumin decreased markedly within 3-weeks' time.

Thus an arbitrary level of 40 per cent of altered protein in the albumin fraction will serve to differentiate between most cases of acute glomerular nephritis and nephrosis, while a value of 50 per cent or more has been found only in nephrosis. A significant amount of altered albumin accompanied by a significant amount of altered globulin seems to indicate nephrosis as does a persistence of a high percentage of altered albumin for a month or longer.

It was hoped that the precipitin test would be of aid in the differential diagnosis between chronic glomerular nephritis with the nephrotic syndrome and pure nephrosis. Four patients with chronic glomerular nephritis were available for study. The data are assembled in Table IV. In 2 of these patients, M. W. and A. A., vascular damage was prominent and nephrotic symptoms were minimal. Edema was not marked, the serum albumin levels were only moderately low, and the serum cholesterol level was only slightly elevated. 
TABLE II

Relationship of the various globulin fractions to the amount of globulin determined by the precipitin method

\begin{tabular}{|c|c|c|c|c|c|c|c|c|}
\hline \multirow[b]{2}{*}{$\begin{array}{l}\text { Patient and } \\
\text { disease }\end{array}$} & \multirow[b]{2}{*}{ Date } & \multicolumn{5}{|c|}{ Howe's method } & \multirow{2}{*}{$\frac{\text { Precipitin }}{\begin{array}{c}\text { Total } \\
\text { globulin }\end{array}}$} & \multirow[b]{2}{*}{ Comment } \\
\hline & & $\underset{\text { min }}{\text { Albu- }}$ & $\underset{\text { ulin }}{\text { Euglob- }}$ & $\begin{array}{l}\text { Pseudo- } \\
\text { globulin } \\
\text { I }\end{array}$ & $\begin{array}{l}\text { Pseudo- } \\
\text { globulin } \\
\text { II }\end{array}$ & $\begin{array}{c}\text { Total } \\
\text { globulin }\end{array}$ & & \\
\hline $\begin{array}{l}\text { S. S. } \\
\text { Nephrosis }\end{array}$ & $\begin{array}{l}\text { May } 27,1937 \\
\text { September } 22,1937 \\
\text { February } 21,1938 \\
\text { May } 26,1938\end{array}$ & $\begin{array}{l}1.41 \\
1.19 \\
1.38 \\
1.81\end{array}$ & \begin{tabular}{l|}
\multicolumn{2}{c}{$g r a$} \\
0.25 \\
1.52 \\
0.06 \\
0.28
\end{tabular} & $\begin{array}{c}1.07 \\
.00 \\
1.14 \\
1.33\end{array}$ & $\begin{array}{l}0 \text { cc. } \\
1.12 \\
0.76 \\
0.96 \\
0.87\end{array}$ & $\begin{array}{l}2.44 \\
2.28 \\
2.16 \\
2.48\end{array}$ & $\begin{array}{l}\text { grams per } \\
100 \text { cc. } \\
2.00 \\
2.41 \\
3.33 \\
3.57\end{array}$ & $\begin{array}{l}\text { Edematous } \\
\text { Edematous } \\
\text { Edematous } \\
\text { Edematous }\end{array}$ \\
\hline $\begin{array}{l}\text { C. C. } \\
\text { Nephrosis }\end{array}$ & $\begin{array}{l}\text { April } 24,1936 \\
\text { April } 30,1936 \\
\text { May 13,1936 } \\
\text { June 3,1936 } \\
\text { June } 17,1936 \\
\text { October } 3,1936 \\
\text { October } 13,1936 \\
\text { February 20,1937 } \\
\text { November 3,1937 }\end{array}$ & $\begin{array}{l}1.68 \\
2.57 \\
3.51 \\
3.44 \\
3.11 \\
1.95 \\
2.47 \\
4.42 \\
4.06\end{array}$ & $\begin{array}{l}0.18 \\
0.15 \\
0.14 \\
0.09 \\
0.09 \\
0.26 \\
0.17 \\
0.17 \\
0.11\end{array}$ & $\begin{array}{l}1.25 \\
1.48 \\
0.82 \\
0.68 \\
1.34 \\
1.21 \\
1.57 \\
1.26 \\
0.54\end{array}$ & $\begin{array}{l}1.05 \\
1.07 \\
1.10 \\
1.44 \\
0.96 \\
1.00 \\
0.69 \\
1.11 \\
1.04\end{array}$ & $\begin{array}{l}2.48 \\
2.70 \\
2.06 \\
2.21 \\
2.39 \\
2.47 \\
2.43 \\
2.54 \\
1.69\end{array}$ & 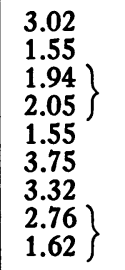 & $\begin{array}{l}\text { Edematous } \\
\text { Diuresis in progress } \\
\text { Regeneration of serum protein } \\
\text { Edematous } \\
\text { Diuresis in progress } \\
\text { Regeneration of serum protein }\end{array}$ \\
\hline $\begin{array}{l}\text { A. F. } \\
\text { Nephrosis }\end{array}$ & $\begin{array}{l}\text { February 10, 1936 } \\
\text { February 19,1936 } \\
\text { March 5, 1936 } \\
\text { March 11,1936 } \\
\text { April 8, 1936 } \\
\text { May 6, 1936 } \\
\text { July 14,1936 } \\
\text { September 22, } 1937\end{array}$ & $\begin{array}{l}0.85 \\
1.72 \\
2.55 \\
3.08 \\
3.41 \\
3.76 \\
4.26 \\
5.23\end{array}$ & $\begin{array}{l}0.16 \\
0.31 \\
0.43 \\
0.36 \\
0.39 \\
0.53 \\
0.54 \\
0.04\end{array}$ & $\begin{array}{l}1.17 \\
1.15 \\
1.14 \\
1.45 \\
0.82 \\
0.79 \\
0.90 \\
1.22\end{array}$ & $\begin{array}{l}0.81 \\
1.14 \\
1.15 \\
1.03 \\
1.31 \\
1.10 \\
1.06 \\
0.87\end{array}$ & $\begin{array}{l}2.14 \\
2.60 \\
2.72 \\
2.84 \\
2.52 \\
2.42 \\
2.50 \\
2.13\end{array}$ & $\left.\begin{array}{l}0.80 \\
4.30 \\
4.67 \\
3.59 \\
2.30 \\
2.31 \\
2.35 \\
2.70\end{array}\right\}$ & $\begin{array}{l}\text { Edematous } \\
\text { Diuresis in progress } \\
\text { Regeneration of serum protein }\end{array}$ \\
\hline J. J. & $\begin{array}{l}\text { November } 15,1937 \\
\text { November 26, } 1937 \\
\text { December 13,1937 } \\
\text { September 9, } 1938\end{array}$ & $\begin{array}{l}1.67 \\
2.56 \\
4.14 \\
5.00\end{array}$ & $\begin{array}{l}0.68 \\
0.49 \\
0.14\end{array}$ & $\begin{array}{l}1.27 \\
1.46 \\
1.43\end{array}$ & $\begin{array}{l}0.22 \\
0.79 \\
0.94\end{array}$ & $\begin{array}{l}2.17 \\
2.74 \\
2.51 \\
1.86\end{array}$ & $\left.\begin{array}{l}2.84 \\
5.37 \\
5.00 \\
1.97\end{array}\right\}$ & $\begin{array}{l}\text { Edematous. Bronchopneumonia } \\
\text { Regeneration of serum protein }\end{array}$ \\
\hline $\begin{array}{l}\text { M. T. } \\
\text { Eczema. } \\
\text { Nutritional } \\
\quad \text { edema }\end{array}$ & $\begin{array}{l}\text { April 23, } 1936 \\
\text { May 4, } 1936 \\
\text { May 21, } 1936\end{array}$ & $\begin{array}{l}1.15 \\
2.01 \\
3.71\end{array}$ & $\begin{array}{l}0.18 \\
0.85 \\
1.52\end{array}$ & $\begin{array}{l}0.58 \\
1.39 \\
1.45\end{array}$ & $\begin{array}{l}0.62 \\
1.23 \\
0.92\end{array}$ & $\begin{array}{l}1.38 \\
3.47 \\
3.89\end{array}$ & $\left.\begin{array}{l}2.02 \\
5.10 \\
8.72\end{array}\right\}$ & Regeneration of serum protein \\
\hline $\begin{array}{l}\text { J. S. } \\
\text { Ulcerative } \\
\text { colitis. } \\
\text { Malnutri- } \\
\text { tion }\end{array}$ & $\begin{array}{l}\text { May } 18,1936 \\
\text { June } 1,1936 \\
\text { June } 24,1936\end{array}$ & $\begin{array}{l}2.52 \\
3.69 \\
3.74\end{array}$ & $\begin{array}{l}0.64 \\
0.90 \\
1.06\end{array}$ & $\begin{array}{l}1.60 \\
1.69 \\
0.62\end{array}$ & $\begin{array}{l}0.67 \\
1.15 \\
1.36\end{array}$ & $\begin{array}{l}2.91 \\
3.74 \\
3.55\end{array}$ & $\left.\begin{array}{l}5.38 \\
7.40 \\
6.51\end{array}\right\}$ & Regeneration of serum protein \\
\hline $\begin{array}{l}\text { P. S. } \\
\text { Eczema. } \\
\text { Nutritional } \\
\quad \text { edema }\end{array}$ & $\begin{array}{l}\text { April 14, } 1936 \\
\text { April 25, } 1936 \\
\text { May } 12,1936\end{array}$ & $\begin{array}{l}1.56 \\
2.61 \\
4.56\end{array}$ & $\begin{array}{l}.00 \\
0.17 \\
0.14\end{array}$ & $\begin{array}{l}0.68 \\
0.93 \\
1.02\end{array}$ & $\begin{array}{l}0.63 \\
1.23 \\
1.15\end{array}$ & $\begin{array}{l}1.31 \\
2.33 \\
2.31\end{array}$ & $\left.\begin{array}{l}1.70 \\
2.18 \\
2.66\end{array}\right\}$ & Regeneration of serum protein \\
\hline
\end{tabular}

The serological changes of the serum proteins were likewise not marked and there was little change in the globulin fraction. Both children died in uremia. In contrast in the other 2 patients, E. L. and E. P., the nephrotic manifestations were marked, generalized anasarca was present, the serum albumin levels were low, and the serum cholesterol was high. In these 2 patients the serological changes were marked in both the albumin and the globulin fractions.
These patients died of pneumococcic septicemia and peritonitis. Thus it is not possible to differentiate between chronic glomerular nephritis (nephrotic stage) and pure nephrosis by the precipitin method.

4. What is the nature of the altered protein? Previously it had been determined that the failure of nephrotic serum to react completely with specific antisera was not due to the high cholesterol content nor to the distribution of the globulin 
TABLE III

Analyses of sera from cases of acute glomerular nephritis. Comparison of Howe's method and the precipitin method

\begin{tabular}{|c|c|c|c|c|c|c|c|c|c|}
\hline \multirow[b]{2}{*}{ Patient, age, date } & \multicolumn{3}{|c|}{ Albumin } & \multicolumn{3}{|c|}{ Globulin } & \multirow[b]{2}{*}{$\underset{\text { uris }}{\text { bumin- }}$} & \multirow[b]{2}{*}{$\begin{array}{c}\text { Edo- } \\
\text { ma }\end{array}$} & \multirow[b]{2}{*}{$\begin{array}{l}\text { Cho- } \\
\text { les } \\
\text { terol }\end{array}$} \\
\hline & Howe & $\begin{array}{l}\text { Pro- } \\
\text { oip- } \\
\text { itin } \\
\text { nor- } \\
\text { mal }\end{array}$ & $\underset{\text { tered }}{\text { Al- }}$ & Howe & $\begin{array}{l}\text { Pre- } \\
\text { cip- } \\
\text { itin } \\
\text { nor- } \\
\text { mal }\end{array}$ & tered & & & \\
\hline $\begin{array}{l}\text { E. P. 8 years } \\
\text { Mareh 11, 1937 } \\
\text { Mareh 22, } 1937 \\
\text { April } 9,1937 \\
\text { Aprl 27, 1937 } \\
\text { May 18, 1937 } \\
\text { June 1, 1937 } \\
\text { June 11, 1937 } \\
\text { September 22, } 1937\end{array}$ & $\begin{array}{l}4.08 \\
3.84 \\
3.74 \\
3.86 \\
4.41 \\
4.46 \\
4.52 \\
4.64\end{array}$ & $\begin{array}{l}3.26 \\
2.94 \\
3.19 \\
3.19 \\
3.72 \\
3.52 \\
4.05 \\
4.19\end{array}$ & $\begin{array}{l}0.82 \\
0.90 \\
0.55 \\
0.67 \\
0.69 \\
0.94 \\
0.47 \\
0.45\end{array}$ & $\begin{array}{l}2.71 \\
2.49 \\
2.12 \\
1.96 \\
1.92 \\
1.84 \\
2.09 \\
2.11\end{array}$ & $\begin{array}{l}2.78 \\
2.21 \\
1.95 \\
1.60 \\
1.65 \\
1.76 \\
2.13 \\
2.17\end{array}$ & $\begin{array}{c}0 \\
0.28 \\
0.17 \\
0.36 \\
0.27 \\
0.08 \\
0 \\
0\end{array}$ & & $\begin{array}{l}\mathbf{0} \\
\mathbf{0} \\
\mathbf{0} \\
\mathbf{0} \\
\mathbf{0} \\
\mathbf{0} \\
\mathbf{0} \\
\mathbf{0}\end{array}$ & $\begin{array}{l}\text { mom. } \\
\text { per } \\
100 \\
c c . \\
217 \\
331 \\
303 \\
284 \\
306 \\
307 \\
305\end{array}$ \\
\hline $\begin{array}{l}\text { R. DeG. } 11 \text { years } \\
\text { Pobruary 11, } 1936 \\
\text { Fobruary 18, } 1936 \\
\text { Maroh 5, } 1836 \\
\text { Mareh } 25,1936 \\
\text { April 1, } 1936 \\
\text { April 15, } 1936 \\
\text { April 29, 1936 } \\
\text { May 13, 1936 } \\
\text { July 1, 1936 } \\
\text { Ootober 28, } 1936 \\
\text { Deoember } 9,1936 \\
\text { January 13, } 1937\end{array}$ & $\begin{array}{l}3.35 \\
4.20 \\
4.17 \\
4.44 \\
4.20 \\
4.21 \\
4.76 \\
4.92 \\
4.68 \\
5.38 \\
4.72 \\
4.49 \\
\end{array}$ & $\begin{array}{l}3.26 \\
3.90 \\
4.18 \\
3.83 \\
4.10 \\
4.11 \\
4.97 \\
5.01 \\
4.90 \\
4.95 \\
4.51 \\
4.43\end{array}$ & $\begin{array}{c}0.09 \\
0.30 \\
0 \\
0.61 \\
0.10 \\
0.10 \\
0 \\
0 \\
0 \\
0.43 \\
0.21 \\
0.06\end{array}$ & $\begin{array}{l}2.42 \\
3.49 \\
3.20 \\
2.77 \\
3.20 \\
2.73 \\
2.82 \\
2.30 \\
2.30 \\
2.57 \\
2.04 \\
2.00\end{array}$ & $\begin{array}{l}2.40 \\
3.95 \\
3.20 \\
2.86 \\
3.57 \\
2.92 \\
3.12 \\
2.94 \\
2.52 \\
3.05 \\
2.80 \\
2.07\end{array}$ & $\begin{array}{c}0.02 \\
0 \\
0 \\
0 \\
0 \\
0 \\
0 \\
0 \\
0 \\
0 \\
0 \\
0\end{array}$ & $\begin{array}{l}++t \\
++ \\
\pm \\
+ \\
+ \\
\pm \\
\pm \\
\pm \\
\pm \\
0 \\
0 \\
0\end{array}$ & $\begin{array}{c}++ \\
\pm \\
0 \\
0 \\
0 \\
0 \\
0 \\
0 \\
0 \\
0 \\
0 \\
0\end{array}$ & $\begin{array}{l}155 \\
213 \\
216 \\
\\
\\
162 \\
162 \\
168 \\
177 \\
161 \\
156 \\
167 \\
\end{array}$ \\
\hline $\begin{array}{l}\text { L. McM. } 7 \text { years } \\
\text { April 7, } 1936 \\
\text { April 23, 1936 } \\
\text { May 19, 1936 } \\
\text { July 1, 1936 } \\
\text { Ootober 28, } 1936\end{array}$ & $\begin{array}{l}2.95 \\
3.72 \\
4.37 \\
4.03 \\
4.71\end{array}$ & $\begin{array}{l}2.63 \\
3.06 \\
371 \\
3.99 \\
4.66 \\
\end{array}$ & $\begin{array}{l}0.32 \\
0.66 \\
0.66 \\
0.04 \\
0.05\end{array}$ & $\begin{array}{l}2.80 \\
3.02 \\
2.73 \\
2.32 \\
2.54\end{array}$ & $\begin{array}{l}2.94 \\
2.75 \\
3.12 \\
2.33 \\
2.78 \\
\end{array}$ & $\begin{array}{c}0 \\
0.27 \\
0 \\
0 \\
0 \\
\end{array}$ & $++t$ & $\begin{array}{l}+ \\
0 \\
0 \\
0 \\
0\end{array}$ & $\begin{array}{l}210 \\
283 \\
154\end{array}$ \\
\hline $\begin{array}{l}\text { J. MoG. } 9 \text { years } \\
\text { November 3,1936 } \\
\text { November 10,1936 } \\
\text { November 17, } 1936 \\
\text { November 30,1936 } \\
\text { December 6, } 1936 \\
\text { December 16, } 1936 \\
\text { Fobruary 10,1937 } \\
\text { April 21, } 1937\end{array}$ & $\begin{array}{l}3.75 \\
4.49 \\
4.63 \\
4.60 \\
4.64 \\
4.46 \\
4.83 \\
4.85\end{array}$ & \begin{tabular}{l|}
3.48 \\
3.96 \\
3.99 \\
3.97 \\
4.16 \\
4.34 \\
4.80 \\
4.13
\end{tabular} & $\begin{array}{l}0.27 \\
0.53 \\
0.64 \\
0.63 \\
0.48 \\
0.12 \\
0.03 \\
0.72\end{array}$ & $\begin{array}{l}2.45 \\
2.56 \\
2.64 \\
2.64 \\
2.32 \\
2.57 \\
2.03 \\
1.69\end{array}$ & $\begin{array}{l}2.44 \\
2.79 \\
2.50 \\
2.49 \\
2.37 \\
1.88 \\
2.00 \\
1.75\end{array}$ & $\begin{array}{c}0 \\
0 \\
0.14 \\
0.15 \\
0 \\
0.69 \\
0.03 \\
0\end{array}$ & $\begin{array}{l}+ \\
+ \\
+ \\
\pm \\
\pm \\
\pm \\
0 \\
0\end{array}$ & $\begin{array}{l}++ \\
0 \\
0 \\
0 \\
0 \\
0 \\
0 \\
0\end{array}$ & $\begin{array}{l}206 \\
256 \\
261 \\
242 \\
214 \\
205\end{array}$ \\
\hline $\begin{array}{l}\text { J. D. } 5 \text { years } \\
\text { February 3, } 1937 \\
\text { February 11, } 1937 \\
\text { February 23, } 1937 \\
\text { March 25, 1937 } \\
\text { April 10, } 1937 \\
\text { April 16, 1937 } \\
\text { May 5, 1937 } \\
\text { Dooember 16, } 1937\end{array}$ & $\begin{array}{l}2.93 \\
3.64 \\
4.37 \\
4.65 \\
4.64 \\
4.80 \\
4.45 \\
4.80\end{array}$ & \begin{tabular}{|l|}
1.50 \\
1.88 \\
3.66 \\
3.94 \\
4.58 \\
4.53 \\
3.57 \\
4.32
\end{tabular} & $\begin{array}{l}1.43 \\
1.68 \\
0.71 \\
0.71 \\
0.06 \\
0.27 \\
0.88 \\
0.58\end{array}$ & $\begin{array}{l}3.06 \\
3.16 \\
2.68 \\
2.23 \\
2.24 \\
2.02 \\
2.26 \\
1.71\end{array}$ & $\begin{array}{l}3.06 \\
3.24 \\
2.48 \\
2.33 \\
1.85 \\
1.88 \\
2.00 \\
1.84\end{array}$ & $\begin{array}{c}0 \\
0 \\
0.20 \\
0 \\
0.39 \\
0.14 \\
0.26 \\
0\end{array}$ & $\begin{array}{l}0 \\
0 \\
0 \\
0 \\
0 \\
0 \\
0 \\
0\end{array}$ & $\begin{array}{c}++ \\
\pm \\
0 \\
\pm \\
0 \\
0 \\
0 \\
0\end{array}$ & $\begin{array}{l}193 \\
277 \\
284 \\
209 \\
240 \\
209 \\
205 \\
183\end{array}$ \\
\hline $\begin{array}{l}\text { R. V. } 10 \text { months } \\
\text { February 2,1937 } \\
\text { Pebruary 10, } 1937 \\
\text { Mareh } 3,1987 \\
\text { March 20, } 1937\end{array}$ & $\begin{array}{l}3.12 \\
3.33 \\
4.02 \\
3.98\end{array}$ & $\begin{array}{l}1.81 \\
2.11 \\
2.88 \\
2.96\end{array}$ & $\begin{array}{l}1.31 \\
1.22 \\
1.14 \\
1.02\end{array}$ & $\begin{array}{l}2.79 \\
3.52 \\
2.99 \\
3.74\end{array}$ & $\begin{array}{l}2.87 \\
4.07 \\
3.07 \\
4.05\end{array}$ & $\begin{array}{l}\mathbf{0} \\
\mathbf{0} \\
\mathbf{0} \\
\mathbf{0}\end{array}$ & $\begin{array}{l} \pm \\
\pm \\
\pm \\
\pm\end{array}$ & $\begin{array}{l} \pm \\
\mathbf{0} \\
0 \\
0\end{array}$ & $\begin{array}{r}97 \\
97 \\
181 \\
204\end{array}$ \\
\hline
\end{tabular}

sub-fractions. It was assumed that the failure resulted from the presence of varying amounts of an altered albumin and an altered globulin, which were measured by Howe's method but which were inactive immunologically to normal antisera. Support for this assumption has been secured in experiments with absorbed antisera. If nephrotic albumin is a mixture of normal albumin and altered albumin, and, similarly, if ne- phrotic globulin is composed of normal and altered globulin, an antiserum prepared against such nephrotic protein should contain antibodies both to the normal and the altered protein on one condition; namely, that the altered protein be capable of stimulating antibody production in the rabbit. If the antibodies to normal serum were absorbed out, the resulting absorbed antisera should contain antibodies to the altered protein only. The absorbed antisera should then become valuable tools for the identification of altered protein in various pathological sera. If an altered protein could be demonstrated in nephrotic sera by means of the absorbed antisera, the experiments would support the conclusion that the serum proteins in nephrosis differ from normal serum proteins.

Preparation of the antisera. Samples of blood serum were accumulated over a period of 3 weeks from patient $H$. S. at a time when precipitin analyses indicated that about 60 per cent of the albumin was abnormal. From the pooled samples the albumin was isolated as previously described (2) and injected into rabbits to produce an antinephrotic albumin serum. The antibodies to normal albumin were then absorbed out by the addition of small increments of normal serum albumin. The precipitate was always removed by centrifugation with decantation of the supernatant before more albumin was added, and the process was continued until no further precipitate was thrown down. Theoretically, the absorbed antiserum now contained antibodies to the altered albumin only.

Similarly, 3 antinephrotic globulin sera were prepared from nephrotic globulin isolated from patients B. G., H. S., and J. F. In these patients precipitin analyses at the time the blood was withdrawn indicated that about 85 per cent, 70 per cent, and 50 per cent, respectively, of the globulin was abnormal. The antibodies to normal globulin were then absorbed out by the successive addition of small amounts of normal globulin. After a considerable excess of normal globulin had been added, a trace of precipitate continued to form. It was felt that this trace represented the interaction with one of the weaker antigenic components, and that it could be safely ignored, since the antisera were always checked for cross precipitation with normal globulin before use. 


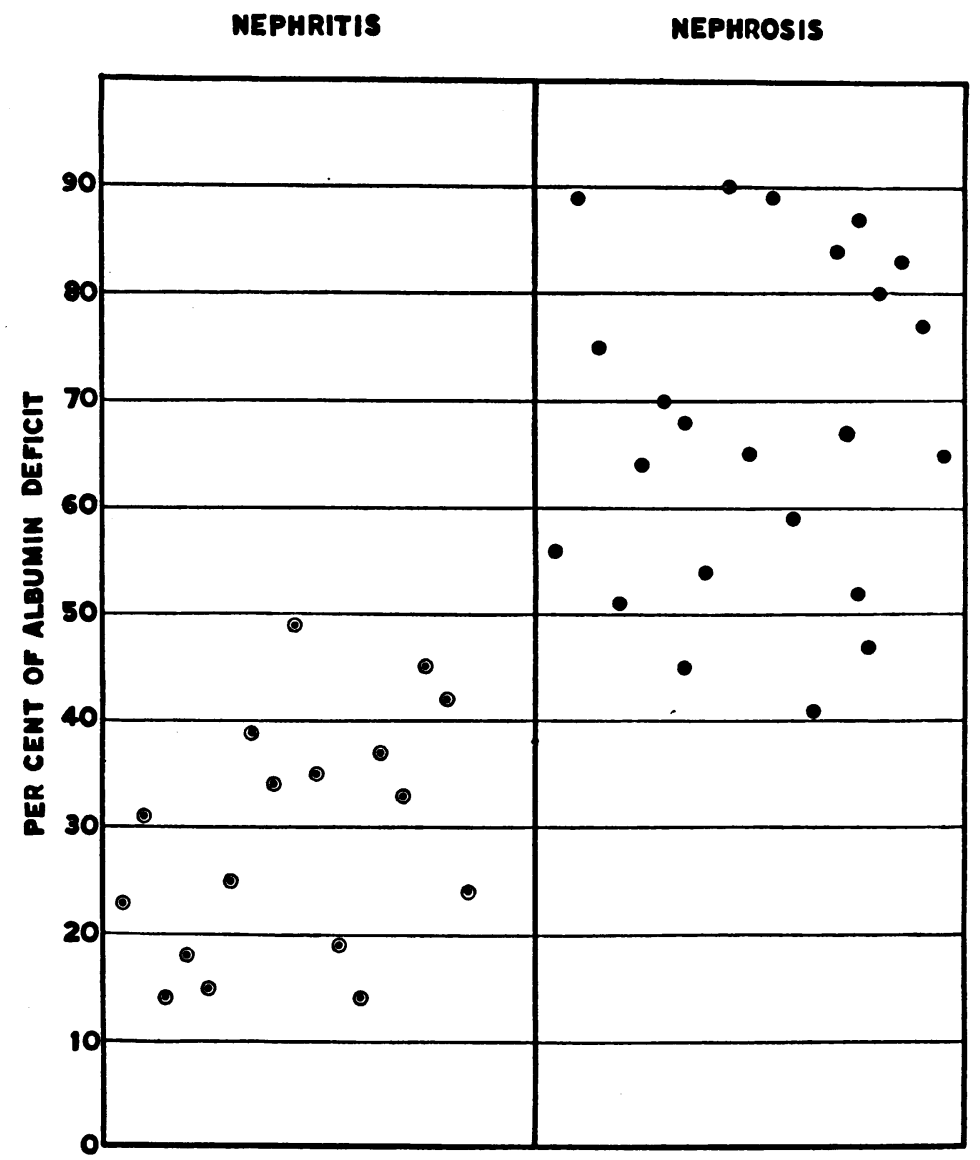

Fig. 5. Comparison of the Maximal Quantities of Altered Albumin in Nephritic and Nephrotic Patients

Thus several types of antisera were available for study :

1. Anti-normal albumin serum.

2. Unabsorbed antinephrotic albumin serum theoretically containing antibodies to normal albumin and altered albumin.

3. Absorbed antinephrotic albumin serum, theoretically containing antibodies to the altered albumin only.

4. Anti-normal globulin serum.

5. Unabsorbed antinephrotic globulin serum which should contain antibodies to normal globulin and to altered globulin.

6. Absorbed antinephrotic globulin serum, which should contain antibodies to the altered globulin only.

Tests with the various anti-albumin sera. In order to study the reactions of normal serum al- bumin and nephrotic serum albumin, both substances were set up against the 3 antisera: the anti-normal albumin serum, the unabsorbed antinephrotic albumin serum, and the absorbed antinephrotic albumin serum. All tests were performed with approximately $0.2 \mathrm{mgm}$. of antigen protein and $1 \mathrm{cc}$. of antiserum in a total volume of $3 \mathrm{cc}$, that is, within the optimum range of the antigen-antibody reaction. To guard against error, the supernatants were always tested for excess antibody. The antigen-antibody precipitates formed were centrifuged, washed twice with saline, and the nitrogen content determined by the micro-Kjeldahl method as previously described (2). The normal albumin used in the tests had been isolated from pooled human serum by precipitation of the globulin at half-saturation with ammonium sulphate and subsequent dialyzation of the filtrate against tap water until free from sul- 
TABLE IV

Analyses of sera from cases of chronic glomerular nephritis. Comparison of Howe's method and the precipitin method

\begin{tabular}{|c|c|c|c|c|c|c|c|c|c|c|}
\hline \multirow[b]{2}{*}{ Patient, age, date } & \multicolumn{3}{|c|}{ Albumin } & \multicolumn{3}{|c|}{ Globulin } & \multirow[b]{2}{*}{$\underset{\text { uria }}{\text { Albumin- }}$} & \multirow[b]{2}{*}{ Edema } & \multirow[b]{2}{*}{$\begin{array}{c}\text { Choles- } \\
\text { terol }\end{array}$} & \multirow[b]{2}{*}{ Comment } \\
\hline & Howe & $\begin{array}{l}\text { Pre- } \\
\text { cip- } \\
\text { itin } \\
\text { nor- } \\
\text { mal }\end{array}$ & $\underset{\text { tered }}{\mathrm{Al}-}$ & Howe & $\begin{array}{l}\text { Pre- } \\
\text { cip- } \\
\text { itin } \\
\text { nor- } \\
\text { mal }\end{array}$ & $\begin{array}{c}\text { Al- } \\
\text { tered }\end{array}$ & & & & \\
\hline $\begin{array}{l}\text { E. L. } \\
\text { May } 20,1936\end{array}$ & 1.17 & 0.31 & 0.86 & 3.02 & 1.56 & 1.46 & $+t+t$ & $+t+t$ & $\begin{array}{c}\text { mgm. per } \\
100 \mathrm{cc} . \\
1117\end{array}$ & $\begin{array}{l}\text { Edema present } 6 \text { months. Died } \\
\text { May } 24,1936 \text {. Septicemia. Per- } \\
\text { itonitis. Pneumococcus. }\end{array}$ \\
\hline $\begin{array}{l}\text { E. P. } \\
\text { May 5, } 1937 \\
\text { June 28, } 1937\end{array}$ & $\begin{array}{l}2.26 \\
1.30\end{array}$ & $\begin{array}{l}1.48 \\
0.26\end{array}$ & $\begin{array}{l}0.78 \\
1.04\end{array}$ & $\begin{array}{l}1.78 \\
1.38\end{array}$ & $\begin{array}{l}1.01 \\
0.77\end{array}$ & $\begin{array}{l}0.77 \\
0.61\end{array} \mid$ & $\begin{array}{l}++++ \\
++++\end{array}$ & $\begin{array}{l}0 \\
+++t\end{array}$ & $\begin{array}{l}666 \\
281\end{array}$ & $\begin{array}{l}\text { Edema present } 4 \text { months. After } \\
\text { diuresis. } \\
\text { Septicemia. Peritonitis. Pneu- } \\
\text { mococcus. Died June 29, } 1937 .\end{array}$ \\
\hline $\begin{array}{l}\text { M. W. } \\
\text { November 22, } 1934 \\
\text { March 7, 1935 } \\
\text { March 14, } 1935 \\
\text { April 10,1936 }\end{array}$ & $\begin{array}{l}2.55 \\
3.22 \\
3.27 \\
1.74\end{array}$ & $\begin{array}{l}1.94 \\
2.81 \\
2.80 \\
0.89\end{array}$ & $\begin{array}{l}0.61 \\
0.41 \\
0.47 \\
0.85\end{array}$ & $\begin{array}{l}1.65 \\
2.85 \\
2.61 \\
1.78\end{array}$ & $\begin{array}{l}1.10 \\
3.07 \\
2.78 \\
2.56\end{array}$ & $\begin{array}{c}0.55 \\
0 \\
0 \\
0\end{array} \mid$ & $\begin{array}{l}+t+ \\
+t \\
+t+t\end{array}$ & $\frac{+}{0}$ & $\begin{array}{l}475 \\
270 \\
310 \\
234\end{array}$ & $\begin{array}{l}\text { Edema present } 3 \text { months. } \\
\text { Convalescence scarlet fever. } \\
\text { ?Peritonitis. Died January 21, } \\
\text { 1938. Uremia. }\end{array}$ \\
\hline $\begin{array}{l}\text { A. A. } \\
\text { February 6, } 1937 \\
\text { September } 15,1937\end{array}$ & $\begin{array}{l}2.51 \\
4.19\end{array}$ & $\begin{array}{l}1.25 \\
3.48\end{array}$ & $\begin{array}{l}1.26 \\
0.71\end{array}$ & $\begin{array}{l}2.11 \\
2.27\end{array}$ & $\begin{array}{l}2.24 \\
2.41\end{array}$ & $\begin{array}{l}0 \\
0\end{array}$ & $\begin{array}{l}++++ \\
+++\end{array}$ & $\begin{array}{l}++ \\
++\end{array}$ & $\begin{array}{l}193 \\
282\end{array}$ & $\begin{array}{l}\text { Edema present } 6 \text { months. Sinu- } \\
\text { sitis. Tetany. } \\
\text { Hemiplegia. Died December 1, } \\
\text { 1937. Uremia. }\end{array}$ \\
\hline
\end{tabular}

phate ion. The nephrotic albumin was that which had served in the preparation of the antinephrotic albumin serum. Only a few tests could be carried out with the nephrotic albumin because the quantity of material was limited, and therefore a saline dilution of serum from the same patient was substituted in most of the tests. The sera of the remaining nephrotic patients were likewise merely diluted with saline without further manipulation. The results obtained are depicted in Table V.

It is evident from the table that normal albumin gave an adequate precipitate with its homologous antiserum as well as a fairly good precipitate with the unabsorbed antinephrotic albumin serum, which indicates that the unabsorbed antinephrotic albumin serum contains antibodies in moderate quantity to normal albumin. However, no precipitate was obtained with the absorbed antinephrotic albumin serum, which proves that all of the antibodies to normal albumin were completely removed from the absorbed antiserum. Now when nephrotic albumin was set up against the anti-normal albumin serum a precipitate was thrown down which was less than one would expect if all of the protein were normal albumin. If the nephrotic albumin from the various patients with nephrosis was composed entirely of normal albumin a precipitate of about $.300 \mathrm{mgm}$.

TABLE $\mathbf{V}$

Reactions of normal and nephrotic albumin with various anti-albumin sera

\begin{tabular}{|c|c|c|c|c|}
\hline \multirow{2}{*}{ Albumin } & \multirow{2}{*}{ Sample } & \multicolumn{3}{|c|}{$\begin{array}{l}\text { Albumin antisera. } \\
\text { Nitrogen in precipitate }\end{array}$} \\
\hline & & Normal & $\begin{array}{c}\text { Nephrotic } \\
\text { unab- } \\
\text { sorbed* }\end{array}$ & $\begin{array}{l}\text { Nephrotic } \\
\text { absorbed* }\end{array}$ \\
\hline .221 Normal .... & Isolated & $\begin{array}{l}m g m . \\
.306\end{array}$ & $\begin{array}{l}m g m . \\
.204\end{array}$ & $\begin{array}{l}m g m . \\
0\end{array}$ \\
\hline .150 Nephrotic. . & Isolated & & & 0 \\
\hline $\begin{array}{l}.130 \text { Nephrotic. } \\
.200 \text { Nephrotic. } \\
.200 \text { Nephrotic. } \\
.180 \text { Nephrotic. }\end{array}$ & $\begin{array}{l}\text { H. S.* } \\
\text { S. S. } \\
\text { W. S. } \\
\text { G. D. }\end{array}$ & $\begin{array}{l}.132 \\
.088 \\
.111 \\
.034\end{array}$ & $\begin{array}{l}.114 \\
.065\end{array}$ & $\begin{array}{l}0 \\
.010 \\
0 \\
0\end{array}$ \\
\hline
\end{tabular}

* Homologous with unabsorbed and absorbed antinephrotic albumin sera. 
of nitrogen would be expected, while actually the values obtained were always less. When nephrotic albumin reacted with the unabsorbed antinephrotic albumin serum a moderate precipitate was formed but with the absorbed antinephrotic albumin serum there was no precipitate except in 1 case when a trace was obtained. These results may be interpreted to indicate that the altered protein in the albumin fraction is not capable of stimulating precipitin antibodies in the rabbit. The experiments need confirmation by the preparation of antisera to the nephrotic albumin isolated from other patients. preparation of 1 of the antisera, was set up with the anti-normal globulin serum and yielded a moderate precipitate; with the homologous unabsorbed antinephrotic serum a larger precipitate was formed. These precipitates would be expected if nephrotic globulin was a mixture of normal and altered protein. Now when isolated nephrotic globulin was set up against the 3 absorbed antinephrotic globulin sera significant precipitates were formed in each instance, irrespective of whether the homologous antigen had served in the preparation of the antisera. Hence, nephrotic globulin isolated from 3 patients contained a sub-

TABLE VI

Reactions of normal and nephrotic globulin with various anti-globulin sera

\begin{tabular}{|c|c|c|c|c|c|c|}
\hline \multirow{2}{*}{ Globulin } & \multirow{2}{*}{ Sample } & \multicolumn{5}{|c|}{$\begin{array}{l}\text { Globulin antisera. } \\
\text { Nitrogen in precipitate }\end{array}$} \\
\hline & & Normal & $\begin{array}{l}\text { Nephrotic* } \\
\text { unabsorbed }\end{array}$ & $\begin{array}{c}\text { Nephrotic* } \\
\text { absorbed No. } 1\end{array}$ & $\begin{array}{c}\text { Nephrotic } \\
\text { absorbed No. } 2\end{array}$ & $\begin{array}{l}\text { Nephrotic ab- } \\
\text { sorbed No. } 3\end{array}$ \\
\hline $\begin{array}{l}\text { mgm. } \\
.236 \text { Normal ... } \\
.243 \text { Nephrotic. } \\
.201 \text { Nephrotic. } \\
.183 \text { Nephrotic. } \\
.228 \text { Nephrotic. } \\
.156 \text { Nephrotic. } \\
.185 \text { Nephrotic. } \\
.173 \text { Nephrotic. } \\
.189 \text { Nephrotic. } \\
.191 \text { Normal... } \\
.170 \text { Normal... }\end{array}$ & $\begin{array}{l}\text { Isolated } \\
\text { B. G.* Isolated } \\
\text { S. S. Edematous April } 22 \\
\text { S. S. Edematous May } 27 \\
\text { S. S. Edematous September } 22 \text {. } \\
\text { A. B. Edematous } \\
\text { G. D. Edematous } \\
\text { J. J. Edematous } \\
\text { W. S. Edematous } \\
\text { D. L. Edema-free† } \\
\text { A. F. Edema-free† }\end{array}$ & $\begin{array}{l}m g m . \\
.204 \\
.108 \\
.149 \\
.146 \\
.186 \\
.166 \\
.099 \\
.144 \\
.162 \\
.151 \\
.175\end{array}$ & $\begin{array}{c}m g m . \\
.083 \\
.215 \\
.150 \\
\\
.159 \\
.129\end{array}$ & $\begin{array}{l}m g m . \\
.031 \\
.146 \\
.125 \\
.108 \\
.118 \\
.097 \\
.082 \\
.082 \\
.090 \\
.051 \\
.039\end{array}$ & $\begin{array}{l}\mathrm{mgm} . \\
.019 \\
.092 \\
\\
.093 \\
.084\end{array}$ & $\begin{array}{l}\text { mgm. } \\
.010 \\
.086 \\
.091 \\
.072\end{array}$ \\
\hline
\end{tabular}

* Homologous with unabsorbed and absorbed antinephrotic globulin sera (No. 1).

† Cured nephrotic patients.

Tests with the various anti-globulin sera. Similarly, in order to compare normal globulin and nephrotic globulin both substances were set up against the various anti-globulin sera: the antinormal globulin serum, the unabsorbed antinephrotic globulin serum, and the 3 absorbed antinephrotic sera. The assembled data in Table VI reveal marked deviation from the analogous albumin studies in some respects. Normal globulin reacted with its homologous antiserum; with the unabsorbed antinephrotic globulin serum a moderate precipitate was formed, which indicates that the unabsorbed antinephrotic globulin serum contained antibodies to normal globulin. Normal globulin reacted with the 3 absorbed antinephrotic sera to give traces of precipitate which by analysis were shown to be insignificant. Nephrotic globulin from patient B. G., which had served in the stance which is not found in normal globulin and which stimulated precipitin antibody formation in the rabbit.

Sera from nephrotic patients were now diluted with saline without further manipulation and set up against the various anti-globulin sera; the results are included in Table VI. The results were analogous to those obtained with the isolated nephrotic globulin in all patients with generalized anasarca ; i.e., precipitates of about. the same magnitude were formed with the absorbed antinephrotic globulin sera. The nephrotic globulin from these patients was not homologous with the absorbed antisera, which increases the significance of the result. The sera from 2 cured nephrotic patients, D. L. and A. F., presented only traces of precipitate with the absorbed antinephrotic globulin sera of about the same magnitude as 
normal globulin. This finding was predictable as an examination of Table I shows that the serum of patient A. F. showed no altered globulin.

Is altered protein present in the sera of patients with diseases other than nephrosis and nephritis? Previous studies of a few patients with edema from other causes than nephritis or nephrosis and a number of dogs with experimental nutritional edema had failed to disclose significant amounts of altered protein in the sera. These studies have now been extended to include patients exhibiting any one of the disturbances which characterize the nephrotic syndrome. Two eczematous patients with nutritional edema resulting from insufficient ingestion of protein were included as examples of severe malnutrition in allergic indi-

TABLE VII

Analyses of sera from cases of malnutrition, hypothyroidism, or hepatomegaly. Comparison of Howe's method and the precipitin method

\begin{tabular}{|c|c|c|c|c|c|c|c|c|c|c|c|}
\hline \multirow{3}{*}{ Patient, age } & \multirow{3}{*}{ Disease } & \multirow{3}{*}{ Date } & \multirow{2}{*}{\multicolumn{3}{|c|}{ Albumin }} & \multicolumn{6}{|c|}{ Globulin } \\
\hline & & & & & & \multicolumn{3}{|c|}{ Total } & \multicolumn{3}{|c|}{ Fractions } \\
\hline & & & Howe & $\begin{array}{l}\text { Precip- } \\
\text { itin } \\
\text { normal }\end{array}$ & $\begin{array}{c}\text { Al- } \\
\text { tered }\end{array}$ & Howe & $\begin{array}{c}\text { Precip- } \\
\text { itin } \\
\text { normal }\end{array}$ & Altered & $\begin{array}{l}\text { Euglob- } \\
\text { ulin }\end{array}$ & 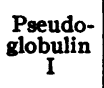 & $\begin{array}{c}\text { Pseudo- } \\
\text { globulin } \\
\text { II }\end{array}$ \\
\hline R. $\mathrm{H}$. & $\begin{array}{l}\text { Laennec's } \\
\text { cirrhosis }\end{array}$ & $\begin{array}{l}\text { March 8, } 1937 \\
\text { April 15, } 1937 \\
\text { April 19, } 1937\end{array}$ & $\begin{array}{l}2.87 \\
2.27 \\
2.42\end{array}$ & $\begin{array}{l}\text { is per } 100 \\
2.28 \\
1.98 \\
1.88\end{array}$ & $\begin{array}{l}c c . \\
0.59 \\
0.29 \\
0.54\end{array}$ & $\begin{array}{l}2.27 \\
1.56 \\
1.39\end{array}$ & $\begin{array}{l}2.34 \\
1.61 \\
1.32\end{array}$ & $\begin{array}{c}\text { grams } \\
0 \\
0 \\
0.07\end{array}$ & $\begin{array}{l}100 \mathrm{cc} . \\
0.32 \\
0.03\end{array}$ & $\begin{array}{l}1.00 \\
0.54\end{array}$ & $\begin{array}{l}0.95 \\
0.99\end{array}$ \\
\hline $\mathrm{R}_{11} \mathrm{~T}$. & $\begin{array}{l}\text { Laennec's } \\
\text { cirrhosis }\end{array}$ & March 26, 1936 & 3.90 & 3.58 & 0.32 & 4.20 & 8.03 & 0 & 0.85 & 1.84 & 1.51 \\
\hline $\begin{array}{l}\text { L. M. } \\
9 \text { years }\end{array}$ & Hepatitis & March 8, 1937 & 3.45 & 3.51 & $\mathbf{0}$ & 5.53 & 8.13 & $\mathbf{0}$ & 1.77 & 2.79 & 0.97 \\
\hline $\begin{array}{l}\text { W. H. } \\
16 \text { months }\end{array}$ & ? Cirrhosis & September 14, 1937 & 5.31 & 4.71 & 0.60 & 1.90 & 1.12 & 0.78 & $\mathbf{0}$ & 0.59 & 1.31 \\
\hline $\begin{array}{l}\text { C. E. } \\
6 \text { years }\end{array}$ & $\begin{array}{l}\text { ? Liver } \\
\text { abscess }\end{array}$ & November 20, 1936 & 3.74 & 3.07 & 0.67 & 5.47 & 11.34 & $\mathbf{0}$ & 2.19 & 2.36 & 0.92 \\
\hline $\begin{array}{l}\text { W. L. } \\
11 \text { years } \\
\text { N. A. } \\
5 \text { years }\end{array}$ & $\begin{array}{l}\text { Amyloidosis } \\
\text { ? Banti's } \\
\text { disease }\end{array}$ & $\begin{array}{l}\text { April 20, } 1937 \\
\text { December 4, } 1937\end{array}$ & $\begin{array}{l}2.78 \\
5.07\end{array}$ & $\begin{array}{l}1.78 \\
4.84\end{array}$ & $\begin{array}{l}1.00 \\
0.23\end{array}$ & $\begin{array}{l}3.03 \\
2.29\end{array}$ & $\begin{array}{l}5.41 \\
2.60\end{array}$ & $\begin{array}{l}0 \\
0\end{array}$ & $\begin{array}{l}0.65 \\
0.30\end{array}$ & $\begin{array}{l}1.09 \\
0.89\end{array}$ & $\begin{array}{l}1.29 \\
1.10\end{array}$ \\
\hline E. J. & $\begin{array}{l}\text { Aplastic } \\
\text { anemia }\end{array}$ & December 4, 1936 & 3.16 & 3.14 & 0.02 & 3.41 & 7.00 & 0 & 0.82 & 1.86 & 0.73 \\
\hline $\begin{array}{l}\text { J. R. } \\
2 \text { months }\end{array}$ & $\begin{array}{l}\text { Syphilitic } \\
\text { hepatitis }\end{array}$ & March 22, 1937 & 3.50 & 3.20 & 0.30 & 3.27 & 3.22 & 0.05 & & & \\
\hline $\begin{array}{l}\text { J. G. } \\
20 \text { months }\end{array}$ & $\begin{array}{c}\text { Hypothy- } \\
\text { roidism }\end{array}$ & February 5, 1936 & 5.08 & 4.37 & 0.71 & 1.50 & 0.99 & 0.51 & & & \\
\hline $\begin{array}{l}\text { M. T. } \\
6 \text { months }\end{array}$ & $\begin{array}{l}\text { Nutritional } \\
\text { edema }\end{array}$ & $\begin{array}{l}\text { April 23, } 1936 \\
\text { May 4, 1936 } \\
\text { June 1, } 1936 \\
\end{array}$ & $\begin{array}{l}1.15 \\
2.01 \\
3.71\end{array}$ & $\begin{array}{l}0.73 \\
0.96 \\
2.60\end{array}$ & $\begin{array}{l}0.42 \\
1.05 \\
1.11\end{array}$ & $\begin{array}{l}1.38 \\
3.47 \\
3.89 \\
\end{array}$ & $\begin{array}{l}2.02 \\
5.10 \\
8.72 \\
\end{array}$ & $\begin{array}{l}0 \\
0 \\
0\end{array}$ & $\begin{array}{l}0.18 \\
0.85 \\
1.52 \\
\end{array}$ & $\begin{array}{l}0.58 \\
1.39 \\
1.45 \\
\end{array}$ & $\begin{array}{l}0.62 \\
1.23 \\
0.92 \\
\end{array}$ \\
\hline T. D. & $\begin{array}{l}\text { Nutritional } \\
\text { edema }\end{array}$ & $\begin{array}{l}\text { March 19, } 1937 \\
\text { April 5, } 1937\end{array}$ & $\begin{array}{l}1.85 \\
2.75\end{array}$ & $\begin{array}{l}1.66 \\
2.78\end{array}$ & $\begin{array}{c}0.19 \\
0\end{array}$ & $\begin{array}{l}1.43 \\
1.68\end{array}$ & $\begin{array}{l}0.95 \\
0.89\end{array}$ & $\begin{array}{l}0.48 \\
0.79\end{array}$ & . & & \\
\hline P. $S$ years & $\begin{array}{l}\text { Nutritional } \\
\text { edema }\end{array}$ & $\begin{array}{l}\text { April 14, } 1936 \\
\text { April 25, } 1936 \\
\text { May 12, } 1936\end{array}$ & $\begin{array}{l}1.56 \\
2.61 \\
4.56\end{array}$ & $\begin{array}{l}1.09 \\
2.07 \\
3.87\end{array}$ & $\begin{array}{l}0.47 \\
0.54 \\
0.69\end{array}$ & $\begin{array}{l}1.31 \\
2.33 \\
2.31\end{array}$ & $\begin{array}{l}1.70 \\
2.18 \\
2.66\end{array}$ & $\begin{array}{c}0 \\
0.15 \\
0\end{array}$ & $\begin{array}{c}0 \\
0.17 \\
0.14\end{array}$ & $\begin{array}{l}0.68 \\
0.93 \\
1.02\end{array}$ & $\begin{array}{l}0.63 \\
1.23 \\
1.15\end{array}$ \\
\hline J. S. & $\begin{array}{l}\text { Ulcerative } \\
\text { colitis }\end{array}$ & May 18,1936 & 2.52 & 1.61 & 0.91 & 2.91 & 5.38 & 0 & 0.64 & 1.60 & 0.67 \\
\hline 12 years & $\begin{array}{l}\text { Nutritional } \\
\text { edema }\end{array}$ & $\begin{array}{l}\text { June } 1,1936 \\
\text { June } 24,1936\end{array}$ & $\begin{array}{l}3.69 \\
3.74\end{array}$ & $\begin{array}{l}3.15 \\
3.80\end{array}$ & $\begin{array}{c}0.54 \\
0\end{array}$ & $\begin{array}{l}3.74 \\
3.55\end{array}$ & $\begin{array}{l}7.40 \\
6.51\end{array}$ & $\begin{array}{l}\mathbf{0} \\
\mathbf{0}\end{array}$ & $\begin{array}{l}0.90 \\
0.62\end{array}$ & $\begin{array}{l}1.69 \\
1.36\end{array}$ & $\begin{array}{l}1.15 \\
1.57\end{array}$ \\
\hline
\end{tabular}


viduals. One patient with ulcerative colitis exhibited hypoproteinemia because of failure to absorb ingested protein. One patient with hypothyroidism was selected because of the high cholesteremia. Since the liver is supposed to share in the synthesis of serum protein, a number of patients with various types of severe liver. damage were investigated. The data are assembled in Table VII.

In none of the patients were maximal amounts of altered protein encountered; nevertheless in the 2 patients with nutritional edema due to an extreme degree of hypoproteinemia, the values found were at the lower level of the empirical borderline selected to differentiate nephrotic sera. In 1 of these patients, M. T., with a total protein of 2.53 grams per $100 \mathrm{cc}$. of serum, there was 48 per cent of altered albumin. In a similar patient, T. D., with a total serum protein of 3.58 grams per 100 cc., the albumin was normal but the globulin revealed 47 per cent of altered protein.

In no case of severe liver damage analyzed was there a significant amount of altered albumin or altered globulin. In 1 patient, W. L., the altered albumin was found to be 36 per cent; this child was in the terminal stage of tuberculous enteritis with severe malnutrition and amyloidosis subsequently proven by autopsy. The globulin values obtained by the precipitin method in the cases of liver damage were usually high, since the euglobulin and pseudoglobulin fractions were also high (1), and in no case was there an appreciable amount of altered globulin.

Sera from most of the patients with liver damage were tested against the 3 absorbed antinephrotic globulin sera to determine whether the globulin from these patients contained any of the altered protein found in nephrosis. No reaction occurred and the conclusion seems justified that in the patients with liver damage the serum globulin is not identical with that found in nephrosis. Further studies are necessary before an interpretation of the results in terms of the relation of altered protein to the etiology of nephrosis can be hazarded. It would seem, however, that even in extremely severe states of malnutrition repre- sented by such patients as M. T., T. D., and J. S., without liver disease, and $R . H$. and W. L. with liver damage, changes in the serum protein never reach the maximal values so commonly found in nephrosis.

\section{CONCLUSIONS}

In the sera of 23 cases of nephrosis examined during the edematous stage the quantitative precipitin method revealed evidence of an altered protein in the albumin fraction, which was usually associated with an altered protein in the globulin fraction. Maximal amounts of altered protein may be present very early in the course of the disease. The altered protein persists for long periods of time.

The patients whose sera show maximal amounts of altered protein are not more susceptible to superimposed infection than those with lesser change; no relation could be demonstrated between the amount of altered serum albumin and the albuminuria, cholesteremia, or edema.

Quantitative precipitin studies on the sera of 17 cases of acute glomerular nephritis revealed minimal amounts of altered protein in the albumin fraction with rarely any associated altered globulin. The changes were transient.

Evidence has been presented in support of the assumption that the failure of the protein of nephrotic serum to react completely with rabbit antisera is due to the presence of altered protein in the albumin and globulin fractions. The altered protein in the globulin fraction of 3 patients forms antibodies when injected into the rabbit which do not react with normal globulin; the antibodies react with nephrotic sera drawn during the edematous stage of nephrosis but not with the sera of cured nephrotics. The altered protein in the serum albumin of 1 patient was not capable of stimulating antibody formation in the rabbit.

No evidence was obtained from precipitin studies on the sera of patients with various diseases other than nephrosis to indicate that severe malnutrition, hypothyroidism, or liver damage causes serological changes of the same magnitude as those found in nephrotic patients. 


\section{BIBLIOGRAPHY}

1. Goettsch, E., and Reeves, E. B., Observations on the nature of the serum proteins in nephrosis. J. Clin. Invest., 1936, 15, 173.

2. Goettsch, E., and Kendall, F. E., Analysis of albumin and globulin in biological fluids by the quantitative precipitin method. J. Biol. Chem., 1935, 109, 221.
3. Schoenheimer, R., and Sperry, W. M., A micromethod for the determination of free and combined cholesterol. J. Biol. Chem., 1934, 106, 745.

4. Sperry, W. M., and Lyttle, J. D., Relationship between total and free cholesterol of the blood serum in healthy and in diseased children. Am. J. Dis. Child., 1936, 52, 760. 